\title{
Morphological and Nutritional Properties of Popular Eggplant Cultivars in Bangladesh
}

\author{
AKM Quamruzzaman (Corresponding Author) \\ Olericulture Division, Horticulture Research Center, Bangladesh Agricultural Research \\ Institute, Joydebpur, Gazipur-1701, Bangladesh \\ Email: akmqzs@gmail.com
}

Anjumanara Khatun

Vegetable Research Technology Section, Institute of Food Science and Technology, Bangladesh Council of Scientific and Industrial Research, Dhaka, Bangladesh

Email: anjuzamanmmm@gmail.com

\begin{abstract}
F. Islam
Olericulture Division, Horticulture Research Center, Bangladesh Agricultural Research Institute, Joydebpur, Gazipur-1701, Bangladesh

Email: ive_bari@yahoo.com
\end{abstract}

Received: June 27, 2020 Accepted: July 19, 2020

doi:10.5296/jbls.v11i2.17407 URL: https://doi.org/10.5296/jbls.v11i2.17407

\begin{abstract}
The study was conducted to investigate the morphological characteristics, nutritional composition, compare the proximal composition, mineral content and antioxidant bioactive compounds of ten popular eggplant (Solanum melongena L.) cultivars (six OP and four hybrids) in Bangladesh during the winter season of 2019-20. Considering the growth habit, plant vigour, earliness, fruit shape, fruit colour, fruit no/plant, fruit yield, pest and diseases infestation BARI Begun-6, BARI Begun- 8, BARI Begun-10, SM275, BARI Hybrid Begun-4 and Hybrid 21x11 were superior in comparison to other cultivars. BARI Begun-6 showed the highest amount of Carbohydrate (6.63) and $\mathrm{Ca}$ (48.33), while BARI Begun- 8 was highest for crude fiber (2.48), ash (0.62), protein (1.54) and Mn (0.40). BARI Begun-10 obtained the highest content of energy (32.1), anthocyanin (78.51), P (23.45) and Zn (0.57). SM275
\end{abstract}


showed the highest concentration of ascorbic acid (15.21), $\mathrm{Na}$ (8.51) and $\mathrm{Mg}$ (24.80). In both studies the four OP cultivars viz., BARI Begun-6, BARI Begun-8, BARI Begun-10, SM275 and one hybrid viz., Hybrid 21x11 performed well with better horticultural characters along with significant amounts of human promoting health components, such as crude fibre and biologically essential minerals like $\mathrm{K}, \mathrm{Ca}, \mathrm{Mg}, \mathrm{P}, \mathrm{Na}$ and Fe. These cultivars can be cultivated and consumed for better human health.

Keywords: nutritional content, mineral content, antioxidant capacity, ascorbic acid (Vitamin C), proximate composition, eggplant, Solanum melongena L.

\section{Introduction}

Eggplant (Solanum melongena) usually known as brinjal in south Asia (especially Pakistan, India, and Bangladesh), aubergine in Europe, melongene in West Indies, Guinea squash in America and patlican in Turkey. It belongs to the family Solanacea, and is an economically important vegetable crop in the tropics and subtropics. Eggplant's fruit is very nutritious and used for medicinal purposes due to its composition, which includes: very low in calories and contain minerals like potassium, calcium, magnesium, sodium, iron and phytochemicals that contain phenolic components (caffeine and chlorogenic acid), flavonoids, mainly nasunin (Mohamed et al., 2003; Raigon et al., 2008) as well as dietary fibre that is helpful for our health (USDA, 2014; Sanchez-Castillo et al., 1999). Nasunin or delphinidin -3 - (coumaroyl- rutinoside) -5-glucoside is a key phytochemical in brinjal that is widely present in the peel of eggplant (Matsuzoe et al., 1999). Fruits and vegetables are the main dietary sources of phenolic compounds for humans, with phenolic acids and flavonoids being the most abundant (Scalbert and Williamson, 2000; Manach et al., 2004). Eggplant is ranked amongst the - top ten vegetables that provide the healthiest food with low calories and also contain high phenolic contents that are helpful in radical absorbing capacity (Cao et al., 1996, Caguiat and Hautea, 2014).

A wide range of secondary metabolites along with primary metabolites are produced by plants that influence human nutrition and health as well (Korkmaz et al., 2018). Primary metabolites are proteins, vitamins, lipids and carbohydrates, etc. which are mainly involved in developmental and physiological developments of plants that are also vital in our diet (Sevindik et al., 2018). Secondary metabolites are those phytochemicals that often play a crucial role against different stresses, but are not important for basic processes of the plant (Sevindik et al., 2017). Moreover, these phytochemicals are a vital basis for various medicines and the pharmaceutical industry. Even recent modern and traditional remedies mainly depend on these phytochemicals (Sevindik, 2019).

Fruit from eggplants are available in the market throughout the year, as they are generally grown twice or thrice in a year. The fruit of eggplants display a variety of shapes (egg to long club shaped) and colours from white, green, yellowish and different shades of purple and black (Sihachkr et al., 1993). Eggplant cultivars produce fruits with a wide diversity of shapes, sizes and colours (Kashyap et al., 2003; Kantharajah and Golegaonkar, 2004). Various forms, colours and shapes of eggplants are found throughout Southeast Asia, suggesting that this area is an important center of variation and possibly of origin. Vavilov (1928) suggested that its center of origin was in the Indo-Burma region. It originated in India but has a secondary center 


\section{MInstitute ${ }^{\text {Mum }}$}

Journal of Biology and Life Science ISSN 2157-6076 2020, Vol. 11, No. 2

of variation in China. In China, eggplant has been known for the last 1,500 years. It is extensively grown in Bangladesh, India, Pakistan, Nepal, China, Japan and the Philippines. We think different types of eggplants will contain the different nutritional qualities as well as the physiological characteristics. It is therefore necessary to study the individual eggplant cultivars for their nutrition status. The aim of this work was to study the morphological characteristics, nutritional composition and to compare the proximal composition, mineral content and antioxidant bioactive compounds of the popular eggplant cultivars in Bangladesh.

\section{Research Methods}

\subsection{Experimental Site}

The investigation was conducted at the Olericulture Division of Horticulture Research Centre, Bangladesh Agricultural Research Institute (BARI). The laboratory work was done at Vegetable Research Technology Section, Institute of Food Science and Technology, Bangladesh Council of Scientific and Industrial Research, Dhaka, Bangladesh, during 2019-20. The experimental field was at $23.9920^{\circ} \mathrm{N}$ Latitude and $90.4125^{\circ} \mathrm{E}$ Longitude having an elevation of $8.2 \mathrm{~m}$ from sea level under agro-ecological zone (AEZ) 28 (Anon., 1995). The experimental site is situated in the sub-tropical climatic zone and characterized by scanty rainfall during the experimental period. The average minimum and maximum temperature were $18.37^{\circ} \mathrm{C}$ and $29.37^{\circ} \mathrm{C}$.

\subsection{Plant Materials}

Ten types of eggplant cultivars viz., BARI Begun-4, BARI Begun-6, BARI Begun- 8, BARI Begun-10, BARI Hybrid Begun-2, BARI Hybrid Begun-4, SM233, SM275, Hybrid 5x216 and Hybrid 21x11 were used in this study (Figure 1).
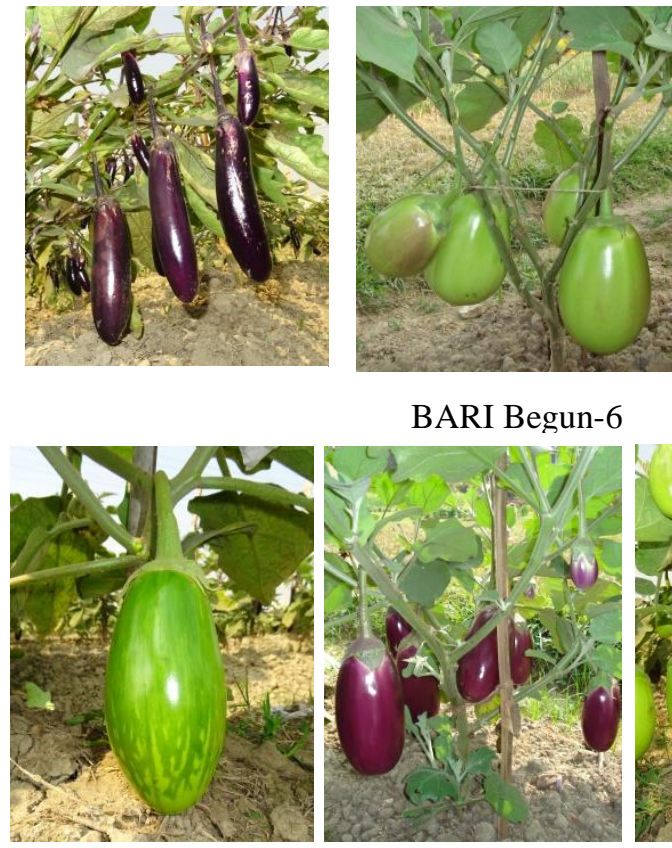

SM275

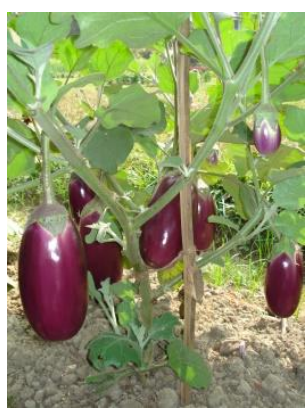

BARI Hybrid Begun-2

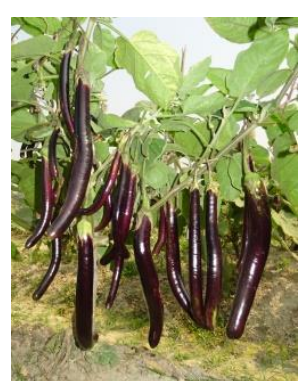

BARI Begun-8

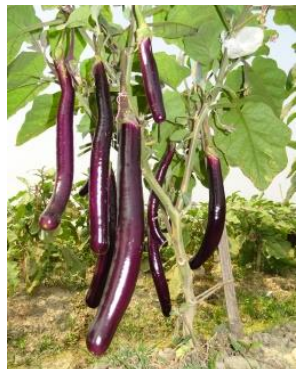

BARI Begun-10

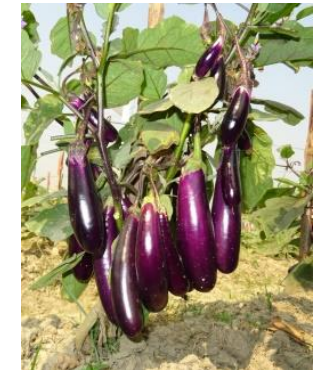

SM233

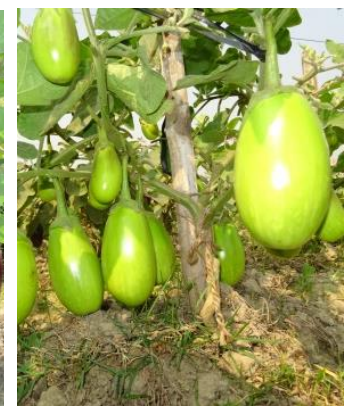

BARI Hybrid Begun-4

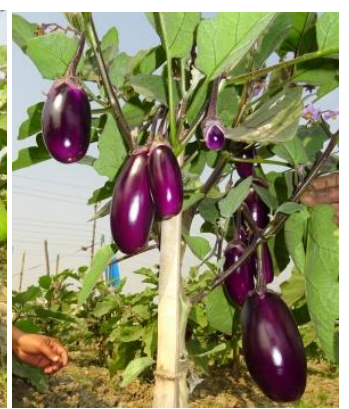

Hybrid 5x216

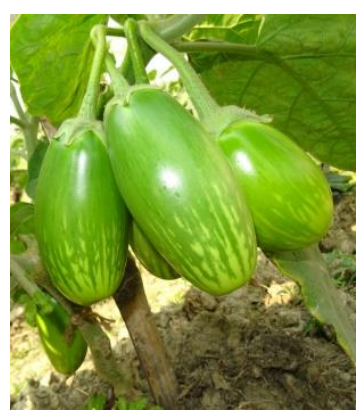

Hybrid 21x 11

Figure 1. Morphological differences among eggplant cultivars in Bangladesh 


\subsection{Sample Preparation}

Eggplant fruits from the representative ten types of cultivars viz., BARI Begun-4, BARI Begun-6, BARI Begun-8, BARI Begun-10, BARI Hybrid Begun-2, BARI Hybrid Begun-4, SM233, SM275, Hybrid 5x216 and Hybrid 21x11 were harvested at commercial mature stage from the experimental farm of Olericulture Division, Horticulture Research Centre, Bangladesh Agricultural Research Institute (BARI), during 2019-20 (23.9920 N Latitude and $90.4125^{\circ}$ E Longitudes). The fruits were washed and sorted by colour and size and divided into two groups. The first group was used fresh for proximate and mineral analysis, while the second group was freeze dried and stored at $-80^{\circ} \mathrm{C}$, for further evaluations of ascorbic acid and anthocyanins.

\subsection{Proximate Composition}

Moisture, ash, protein ( $\mathrm{N}$ x 6.25), crude fibre, fat and carbohydrates (by difference) contents were determined according to AOAC methods (AOAC, 1998).

\subsection{Mineral Content}

Mineral analysis was done based on AOAC methods (AOAC, 1998). Potassium (K), sodium $(\mathrm{Na})$, calcium $(\mathrm{Ca})$, magnesium $(\mathrm{Mg})$, iron $(\mathrm{Fe})$, zinc $(\mathrm{Zn})$, copper $(\mathrm{Cu})$ and manganese $(\mathrm{Mn})$ were determined by atomic absorption spectroscopy using a Varian SpectrAA 220. Phosphorus (P) was determined colourimetrically at $650 \mathrm{~nm}$ in a Varian Cary E1 UV-Vis spectrophotometer.

\subsection{Ascorbic Acid (Vitamin C)}

Ascorbic acid extraction was done according to Ozgur and Sungur (1995) with small modifications as described by Nino-Medina et al. (2014). Ascorbic acid was quantified according to Doner and Hicks (1981) using a Varian Pro Star 330 photodiode array detector HPLC system and a Varian Bondesil $\mathrm{NH}_{2}{ }^{-}$column $(250$ x $4.6 \mathrm{~mm})$. Results were expressed in milligram per 100 gram of eggplant fresh weight.

\subsection{Total Anthocyanins}

Total anthocyanin was determined using a spectrophotometric method adapted from Abdel-Aal and Hucl (1999). An eggplant sample of $0.5 \mathrm{~g}$ was homogenized with $10 \mathrm{~mL}$ of chilled, acidified methanol (95\% methanol and $1 \mathrm{~N} \mathrm{HCl} \mathrm{85:15,v/v).} \mathrm{Solution} \mathrm{absorbance} \mathrm{was}$ measured immediately at 535 and $700 \mathrm{~nm}$. Anthocyanin content was calculated as the concentration of total anthocyanin, expressed as $\mathrm{mg}$ of cyanidin-3-glucoside equivalents per $100 \mathrm{~g}$ of sample (mgC3GE $100 \mathrm{~g}-1)$.

\subsection{Statistical Analysis}

ANOVA was used to assess statistical differences among eggplant types with a 5\% confidence's level. When significant difference was found, Tukey's multiple range tests were carried out to separate means using MSTAT-C. Data were expressed as mean values of three samples. 


\section{Results and Discussion}

\subsection{Morphological Characteristics of Popular Eggplant Cultivars}

In our study, we evaluated ten eggplant cultivars of Bangladesh including six OP and four hybrid cultivars. We evaluated the collection source, horticultural characters [growth habit, plant vigour, earliness (days to $1^{\text {st }}$ harvest), fruit shape, fruit colour, leaf/calyx prickles, bearing habit, fruit length $(\mathrm{cm})$, fruit diameter $(\mathrm{cm})$, individual fruit weight $(\mathrm{g})$ and fruit no/plant], fruit yield, pest and disease infestation [bacterial wilt, little leaf, phomopsis blight, nematode, aphid, jassids and fruit and shoot borer]. Considering the growth habit, plant vigour, earliness (days to $1^{\text {st }}$ harvest), fruit shape, fruit colour, fruit no/plant, fruit yield, pest and disease infestation BARI Begun-6, BARI Begun-8, BARI Begun-10, SM275, BARI Hybrid Begun-4 and Hybrid 21x11 were found to be superior in comparison with the other cultivars (Table 1).

Table 1. Morphological characteristics of popular eggplant cultivars in Bangladesh

\begin{tabular}{|c|c|c|c|c|c|c|c|c|c|c|}
\hline \begin{tabular}{l|} 
Test \\
parameters
\end{tabular} & $\begin{array}{c}\text { BARI } \\
\text { Begun-4 }\end{array}$ & $\begin{array}{c}\text { BARI } \\
\text { Begun-6 }\end{array}$ & $\begin{array}{c}\text { BARI } \\
\text { Begun- } 8\end{array}$ & $\begin{array}{c}\text { BARI } \\
\text { Begun-10 }\end{array}$ & SM233 & SM275 & $\begin{array}{c}\text { BARI } \\
\text { Hybrid } \\
\text { Begun-2 }\end{array}$ & $\begin{array}{c}\text { BARI } \\
\text { Hybrid } \\
\text { Begun-4 }\end{array}$ & $\begin{array}{l}\text { Hybrid } \\
5 \times 216\end{array}$ & $\begin{array}{l}\text { Hybrid } \\
21 \times 11\end{array}$ \\
\hline $\begin{array}{l}\text { Collection } \\
\text { source }\end{array}$ & $\begin{array}{l}\text { Pedigree } \\
\text { selection }\end{array}$ & $\begin{array}{l}\text { Local } \\
\text { collection } \\
\text { Isurdhi, } \\
\text { Bangladesh } \\
\end{array}$ & $\begin{array}{l}\text { Local } \\
\text { collection } \\
\text { Gazipur, } \\
\text { Bangladesh } \\
\end{array}$ & $\begin{array}{l}\text { Local } \\
\text { collection } \\
\text { Norshindhi, } \\
\text { Bangladesh } \\
\end{array}$ & $\begin{array}{l}\text { Pedigree } \\
\text { selection }\end{array}$ & $\begin{array}{l}\text { Local } \\
\text { collection } \\
\text { Jasshore, } \\
\text { Bangladesh } \\
\end{array}$ & $\begin{array}{l}\text { Crossing } \\
\text { material }\end{array}$ & $\begin{array}{l}\text { Crossing } \\
\text { material }\end{array}$ & $\begin{array}{l}\text { Crossing } \\
\text { material }\end{array}$ & $\begin{array}{l}\text { Crossing } \\
\text { material }\end{array}$ \\
\hline $\begin{array}{l}\text { Growth } \\
\text { habit }\end{array}$ & Intermediate & Intermediate & Big & Big & Intermediate & Big & Big & Intermediate & Intermediate & Intermediate \\
\hline $\begin{array}{l}\text { Plant } \\
\text { vigour }\end{array}$ & Moderate & High & Moderate & High & Moderate & High & High & Moderate & Moderate & Moderate \\
\hline $\begin{array}{l}\text { Earliness } \\
\text { (Days to } \\
1^{\text {st harvest) }}\end{array}$ & $\begin{array}{l}\text { Early } \\
100-103\end{array}$ & $\begin{array}{l}\text { Medium } \\
105-108\end{array}$ & $\begin{array}{l}\text { Medium } \\
105-108\end{array}$ & $\begin{array}{l}\text { Medium } \\
105-108\end{array}$ & $\begin{array}{l}\text { Early } \\
100-103\end{array}$ & $\begin{array}{l}\text { Medium } \\
105-108\end{array}$ & $\begin{array}{l}\text { Early } \\
100-103\end{array}$ & $\begin{array}{l}\text { Early } \\
100-103\end{array}$ & $\begin{array}{l}\text { Early } \\
100-103\end{array}$ & $\begin{array}{l}\text { Early } \\
100-103\end{array}$ \\
\hline Fruit shape & $\begin{array}{l}\text { Medium } \\
\text { long, } \\
\text { cylindrical } \\
\text { with round } \\
\text { end }\end{array}$ & Oval & $\begin{array}{l}\text { Long, } \\
\text { cylindrical } \\
\text { with round } \\
\text { end }\end{array}$ & $\begin{array}{l}\text { Long, } \\
\text { cylindrical } \\
\text { with flat } \\
\text { end }\end{array}$ & $\begin{array}{l}\text { Elongate } \\
\text { with round } \\
\text { end }\end{array}$ & Oval & $\begin{array}{l}\text { Oblong } \\
\text { with round } \\
\text { end }\end{array}$ & $\begin{array}{l}\text { Oblong with } \\
\text { round end }\end{array}$ & $\begin{array}{l}\text { Oblong with } \\
\text { round end }\end{array}$ & $\begin{array}{l}\text { Oblong with } \\
\text { round end }\end{array}$ \\
\hline $\begin{array}{l}\text { Fruit } \\
\text { colour }\end{array}$ & $\begin{array}{l}\text { Glossy } \\
\text { uniform } \\
\text { black purple }\end{array}$ & Light green & $\begin{array}{l}\text { Uniform } \\
\text { purple }\end{array}$ & $\begin{array}{l}\text { Shiny dark } \\
\text { purple }\end{array}$ & $\begin{array}{l}\text { Uniform } \\
\text { black purple }\end{array}$ & $\begin{array}{l}\text { Green with } \\
\text { white stripe } \\
\text { at bottom }\end{array}$ & $\begin{array}{l}\text { Uniform } \\
\text { light purple }\end{array}$ & Light green & $\begin{array}{l}\text { Uniform } \\
\text { purple }\end{array}$ & $\begin{array}{l}\text { Green with } \\
\text { white stripe } \\
\text { at bottom }\end{array}$ \\
\hline $\begin{array}{l}\text { Leaf/calyx } \\
\text { prickles }\end{array}$ & Absent & $\begin{array}{l}\text { Absent } \\
\text { (leaves), } \\
\text { few (calyx) }\end{array}$ & $\begin{array}{l}\text { Absent } \\
\text { (leaves), } \\
\text { very few } \\
\text { (calyx) }\end{array}$ & $\begin{array}{l}\text { Absent } \\
\text { (leaves), } \\
\text { few (calyx) }\end{array}$ & $\begin{array}{l}\begin{array}{l}\text { Absent } \\
\text { (leaves), } \\
\text { very few } \\
\text { (calyx) }\end{array} \\
\end{array}$ & $\begin{array}{l}\text { Absent } \\
\text { (leaves), } \\
\text { few (calyx) }\end{array}$ & $\begin{array}{l}\text { Absent } \\
\text { (leaves), } \\
\text { very few } \\
\text { (calyx) }\end{array}$ & $\begin{array}{l}\text { Absent } \\
\text { (leaves), } \\
\text { few (calyx) }\end{array}$ & $\begin{array}{l}\text { Absent } \\
\text { (leaves), } \\
\text { very few } \\
\text { (calyx) }\end{array}$ & $\begin{array}{l}\text { Absent } \\
\text { (leaves), } \\
\text { few (calyx) }\end{array}$ \\
\hline $\begin{array}{l}\text { Bearing } \\
\text { habit }\end{array}$ & Cluster & Solitary & Cluster & Solitary & Cluster & Solitary & Solitary & Cluster & Solitary & Cluster \\
\hline $\begin{array}{l}\text { Fruit } \\
\text { length } \\
\text { (cm) }\end{array}$ & $17-18$ & $10-12$ & $26-28$ & $28-30$ & $17-18$ & $10-12$ & $14-15$ & $10-12$ & $12-14$ & $12-13$ \\
\hline $\begin{array}{l}\text { Fruit } \\
\text { diameter } \\
(\mathrm{cm})\end{array}$ & $3.7-4.2$ & $8-9$ & $3.7-4.2$ & $4.0-4.5$ & $3.7-4.2$ & $8-9$ & $5.0-5.5$ & $5.0-5.5$ & $6.0-6.5$ & $5.0-5.5$ \\
\hline $\begin{array}{l}\text { Individual } \\
\text { Fruit } \\
\text { weight (g) }\end{array}$ & $100-110$ & $230-250$ & $130-140$ & $140-150$ & $100-110$ & $230-250$ & $130-140$ & $100-110$ & $130-140$ & $100-110$ \\
\hline $\begin{array}{l}\text { Fruit } \\
\text { no/plant }\end{array}$ & $45-50$ & $17-20$ & $25-30$ & $22-25$ & $50-55$ & $15-18$ & $22-25$ & $45-50$ & $33-35$ & $40-45$ \\
\hline $\begin{array}{l}\text { Yield/plant } \\
(\mathrm{kg})\end{array}$ & $4.5-5.0$ & $4.0-4.2$ & $3.8-4.0$ & $4.0-4.2$ & $4.5-5.0$ & $4.0-4.2$ & $4.0-4.2$ & $4.0-4.2$ & $4.0-4.2$ & $4.0-4.2$ \\
\hline $\begin{array}{l}\text { Bacterial } \\
\text { wilt }\end{array}$ & Susceptible & $\begin{array}{l}\text { Moderately } \\
\text { tolerance }\end{array}$ & Tolerance & Tolerance & Susceptible & $\begin{array}{l}\text { Moderately } \\
\text { tolerance }\end{array}$ & $\begin{array}{l}\text { Moderately } \\
\text { tolerance }\end{array}$ & $\begin{array}{l}\text { Moderately } \\
\text { tolerance }\end{array}$ & Susceptible & $\begin{array}{l}\text { Moderately } \\
\text { tolerance }\end{array}$ \\
\hline Little leaf & Susceptible & Tolerance & Tolerance & Tolerance & Susceptible & Tolerance & Susceptible & Moderately & Susceptible & Moderately \\
\hline
\end{tabular}




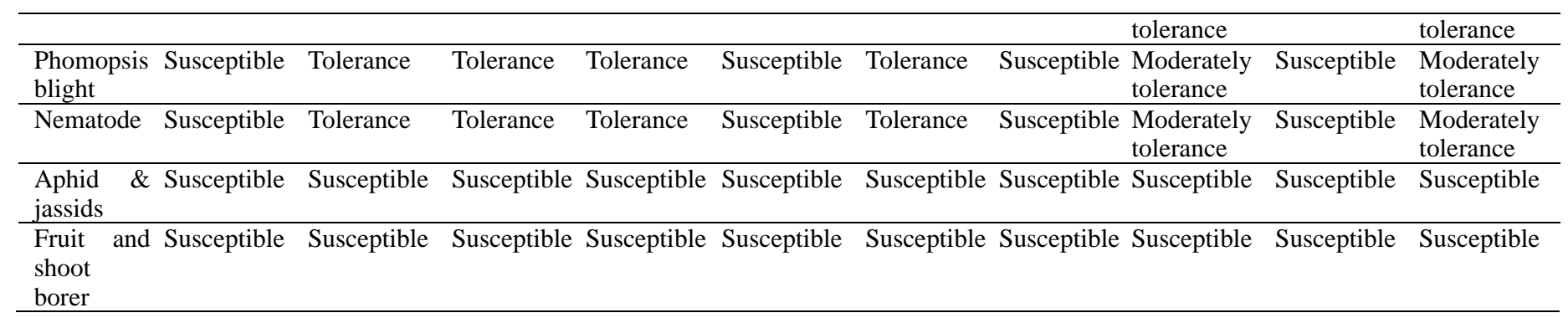

\subsection{Nutritional Composition of Popular Eggplant Cultivars}

\subsubsection{Moisture Content (g 100g ${ }^{1}$ Fresh Weight)}

All eggplant cultivars had moisture contents greater than $90 \%$, ranging from $91.39 \%$ to 94.87\% (Table 2). Higher amounts were observed in BARI Begun-4 (94.87\%), Hybrid 5x216 (94.31\%), moderate amounts were observed in BARI Begun- 8 (93.27\%), BARI Hybrid Begun-2 (93.86\%) and a lower amount was observed in BARI Begun-10 (91.39\%). Flick et al. (1978), Munoz de Chavez et al. (1996) and Maroto (2002) obtained a moisture content ranging from 91.8 to $94.2 \%$, while Nino-Medina et al. (2014) reported a range with smaller values from 90.10 to $92.70 \%$.

\subsubsection{Crude Fiber (g $100 \mathrm{~g}^{1}$ Fresh Weight)}

The crude fiber content of all the cultivars ranged from $1.01 \%$ to $2.48 \%$ (Table 2). The highest amounts were observed in BARI Begun-8 (2.48\%) and BARI Begun-4 (1.92\%), with the lowest amount observed in BARI Begun-6 (1.01\%). Nino-Medina et al. (2014) obtained a crude fiber content ranging from $0.65 \%$ to $1.54 \%$.

\subsubsection{Ash (Total) (g $100 \mathrm{~g}^{1}$ Fresh Weight)}

Generally, ash content levels are less than $1 \%$. In this study the same trend was observed with the range of $0.37 \%-0.61 \%$ (Table 2). Flick et al. (1978), Munoz de Chavez et al. (1996) and Maroto (2002) obtained similar ash content to our study in different cultivars with a range of $0.3 \%$ to $0.7 \%$. Nino-Medina et al. (2014) obtained a range with larger values from $0.36 \%$ to $1.04 \%$ than our study.

\subsubsection{Protein (g $100 \mathrm{~g}^{1}$ Fresh Weight)}

The protein content observed in this study ranged from $0,85 \%$ to $1.54 \%$ (Table 2). The highest values were observed in BARI Begun-8 (1.54\%), BARI Hybrid Begun-4 (1.42\%), followed by BARI Begun-10 (1.38\%) and Hybrid 21x11 (1.38\%), while the lowest value was from BARI Hybrid Begun-2 (0.85 \%). Smaller values were obtained by Flick et al. (1978), Munoz de Chavez et al. (1996) and Maroto (2002) ranging from $0.11 \%$ to $1.2 \%$, while Nino-Medina et al. (2014) obtained a range from $0.65 \%$ to $0.90 \%$. The larger values observed in this study is very encouraging for future breeding.

\subsubsection{Fat (g $100 \mathrm{~g}^{1}$ Fresh Weight)}

The fat content ranged from 0.02 to $0.4 \%$ (Table 2). The highest fat content observed in the eggplant cultivars were BARI Hybrid Begun-2 (0.40\%) followed by BARI Begun-4 (0.19), 
Hybrid 21x11 (0.19\%) and BARI Hybrid Begun-4 (0.17 \%). The lowest value was observed in BARI Begun-10 (0.02\%). Nino-Medina et al. (2014) analyzed the fat content in different eggplant types reporting values ranging from 0.03 to $0.04 \%$.

\subsubsection{Carbohydrate *}

The range of carbohydrate content was from $4.27 \%$ to $6.63 \%$ (Table 2) The maximum content was observed in BARI Begun-6 (6.63\%), Hybrid 5x216 (6.27\%) and SM233 (6.05\%). These results were similar to those obtained by Nino-Medina et al. (2014), where they obtained a carbohydrate content ranging from $5.96 \%$ to $7.92 \%$ in different eggplant types. In our study we observed several low carbohydrate contents in eggplant cultivars which were less than 5\% viz., BARI Begun-8 (4.27\%), BARI Hybrid Begun-4 (4.61\%), BARI Begun-4 (4.73\%), Hybrid 21x11 (4.91\%) and BARI Begun-10 (4.94\%).

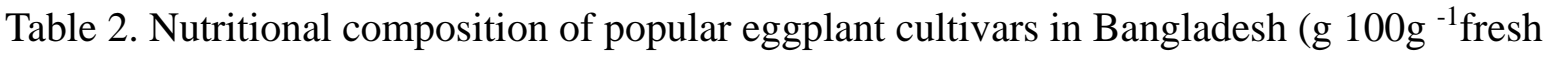
weight)

\begin{tabular}{l|c|c|c|c|c|c|c|c|c|c}
\hline $\begin{array}{l}\text { Test } \\
\text { parameters }\end{array}$ & $\begin{array}{c}\text { BARI } \\
\text { Begun-4 }\end{array}$ & $\begin{array}{c}\text { BARI } \\
\text { Begun-6 }\end{array}$ & $\begin{array}{c}\text { BARI } \\
\text { Begun- } \\
8\end{array}$ & $\begin{array}{c}\text { BARI } \\
\text { Begun-10 }\end{array}$ & SM233 & SM275 & $\begin{array}{c}\text { BARI } \\
\text { Hybrid } \\
\text { Begun-2 }\end{array}$ & $\begin{array}{c}\text { BARI } \\
\text { Hybrid } \\
\text { Begun-4 }\end{array}$ & $\begin{array}{c}\text { Hybrid } \\
5 x 216\end{array}$ & $\begin{array}{c}\text { Hybrid } \\
21 \times 11\end{array}$ \\
\hline $\begin{array}{l}\text { Moisture } \\
\text { content (\%) }\end{array}$ & 94.87 & 92.15 & 93.27 & 91.39 & 92.17 & 93.49 & 93.86 & 92.81 & 94.31 & 92.51 \\
$\begin{array}{l}\text { Crude Fiber } \\
\text { (g/100g) }\end{array}$ & 1.92 & 1.01 & 2.48 & 1.89 & 1.53 & 1.33 & 1.50 & 1.72 & 1.19 & 1.74 \\
$\begin{array}{l}\text { Ash (total) (g } \\
\text { 100g fresh }\end{array}$ & 0.47 & 0.37 & 0.62 & 0.61 & 0.42 & 0.50 & 0.42 & 0.50 & 0.38 & 0.50 \\
$\begin{array}{l}\text { weight) } \\
\text { Protein } \\
\text { (g/100g) }\end{array}$ & 1.05 & 1.04 & 1.54 & 1.38 & 1.02 & 1.12 & 0.85 & 1.42 & 0.95 & 1.38 \\
$\begin{array}{l}\text { Fat (g/100g) } \\
\text { Carbohydrate }\end{array}$ & 0.19 & 0.03 & 0.05 & 0.02 & 0.04 & 0.07 & 0.40 & 0.17 & 0.13 & 0.19 \\
$*$ & 4.73 & 6.63 & 4.27 & 4.94 & 6.05 & 5.72 & 5.20 & 4.61 & 6.27 & 4.91 \\
$\begin{array}{l}\text { Energy } \\
\text { Kcal/100g }\end{array}$ & 19.59 & 30.07 & 24.69 & 32.1 & 29.84 & 24.39 & 24.88 & 27.61 & 21.89 & 28.91 \\
$\begin{array}{l}\text { Sugar (total) } \\
\text { (g/100g) }\end{array}$ & 0.83 & 1.38 & 0.51 & 0.87 & 0.72 & 0.63 & 0.48 & 1.06 & 0.66 & 0.66 \\
\hline
\end{tabular}

\subsubsection{Ascorbic acid (Vitamin C)}

The ascorbic acid content in eggplant cultivars (Figure 2) showed values ranging between

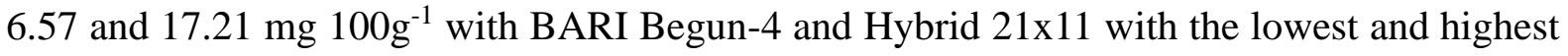
content respectively. All of our results are higher than the $4 \mathrm{mg}$ ascorbic acid $100 \mathrm{~g}^{-1}$ reported in Spain (Esteban et al., 1992) and Turkey (Durust et al., 1997). Prohens et al. (2007) found 1. 4, 1.6 and $1.8 \mathrm{mg}$ ascorbic acid $100 \mathrm{~g}^{-1}$ for a Thai ('Thai Round'), a Chinese ('Kermit') and a European ('Black Beauty') cultivars respectively. On the other hand, Hanson et al. (2006)

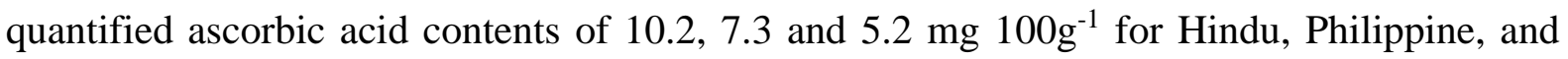
Chinese eggplant types respectively, while Nino-Medina et al. (2014) reported 11.2, 8.6, 8.9 22.0 and $7.4 \mathrm{mg}$ ascorbic acid $100 \mathrm{~g}^{-1}$ for Chinese, Philippines, American, Hindu and Thai types respectively. To put consumption in perspective, Young (1999) suggested a recommended daily intake (RDI) of vitamin $\mathrm{C}$ in the range from 60 to $100 \mathrm{mg}$. Eggplant consumptions of $100 \mathrm{~g} \mathrm{day}^{-1}$ as analyzed in this study, will account for 6 to $17 \%$ of the RDI. 


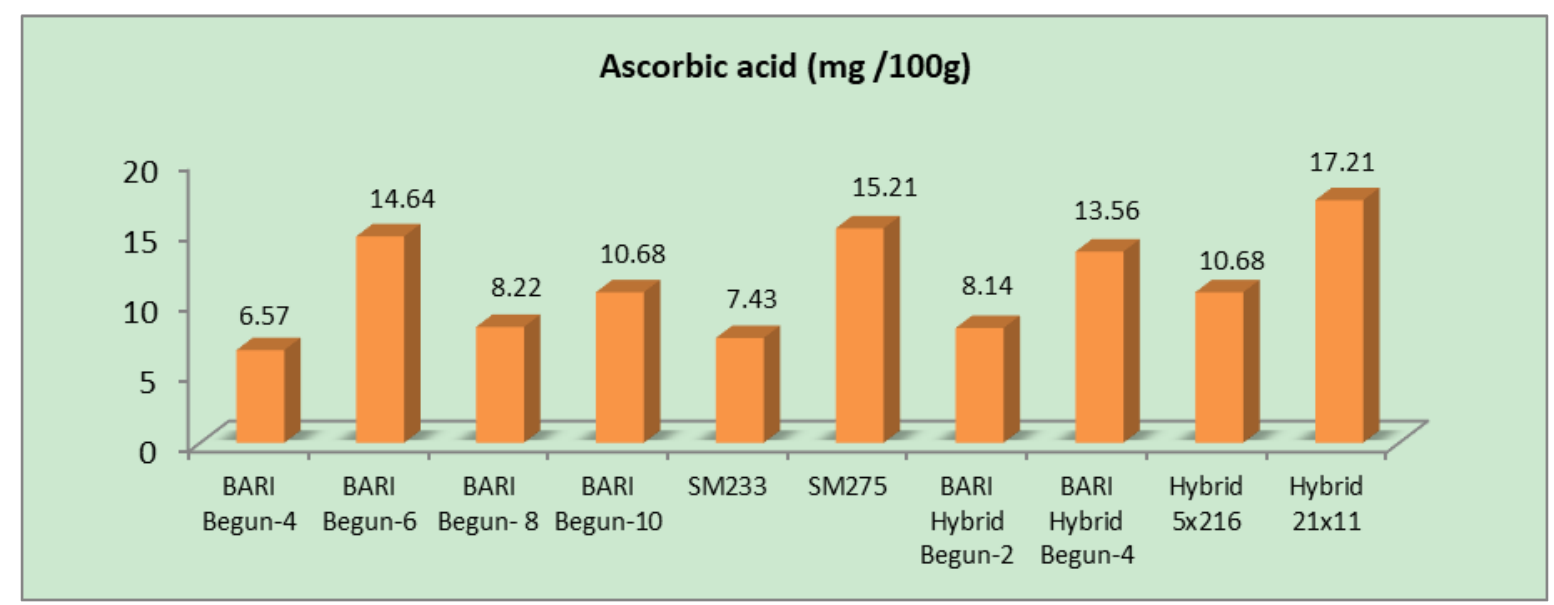

BARI Begun-4

Figure 2. Ascorbic acid (Vitamin C) amount (mg/100g) of popular eggplant cultivars in

Bangladesh

\subsubsection{Anthocyanins}

Among the purple eggplant types, the highest amount of anthocyanins was observed in BARI Begun-10 with $78.51 \mathrm{mg}$ C3GE $100 \mathrm{~g}^{-1}$ ), followed by BARI Hybrid Begun-2 (67.81 mg C3GE $100 \mathrm{~g}^{-1}$ ), Hybrid 5x216 (63.45 mg C3GE $100 \mathrm{~g}^{-1}$ ), while the lowest result was found in BARI Begun-4 with $45.20 \mathrm{mg} \mathrm{C} 3 \mathrm{GE} 100 \mathrm{~g}^{-1}$ (Figure 3). In case of green type eggplants, the

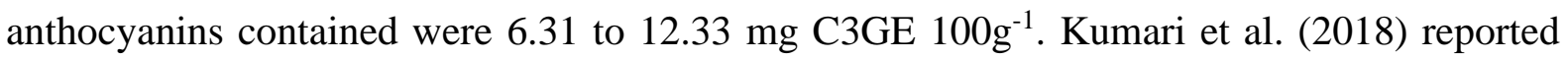
that the fruits of green and white colour have low or negligible anthocyanin content, which is a supplement to our study. Anthocyanins data obtained in this study of purple fruits are similar or slightly higher than those reported by Papanga et al. (1999) and Sadilova et al. (2006) whom reported 55 and $64 \mathrm{mg} 100 \mathrm{~g}^{-1}$, respectively. On the other hand, our anthocyanins data in BARI Begun-10 and Hybrid 5x216 are similar to those reported by Lo Scalzo et al. (2010) and Koponen et al. (2007) who measured 90 and 107 mg 100g-1.

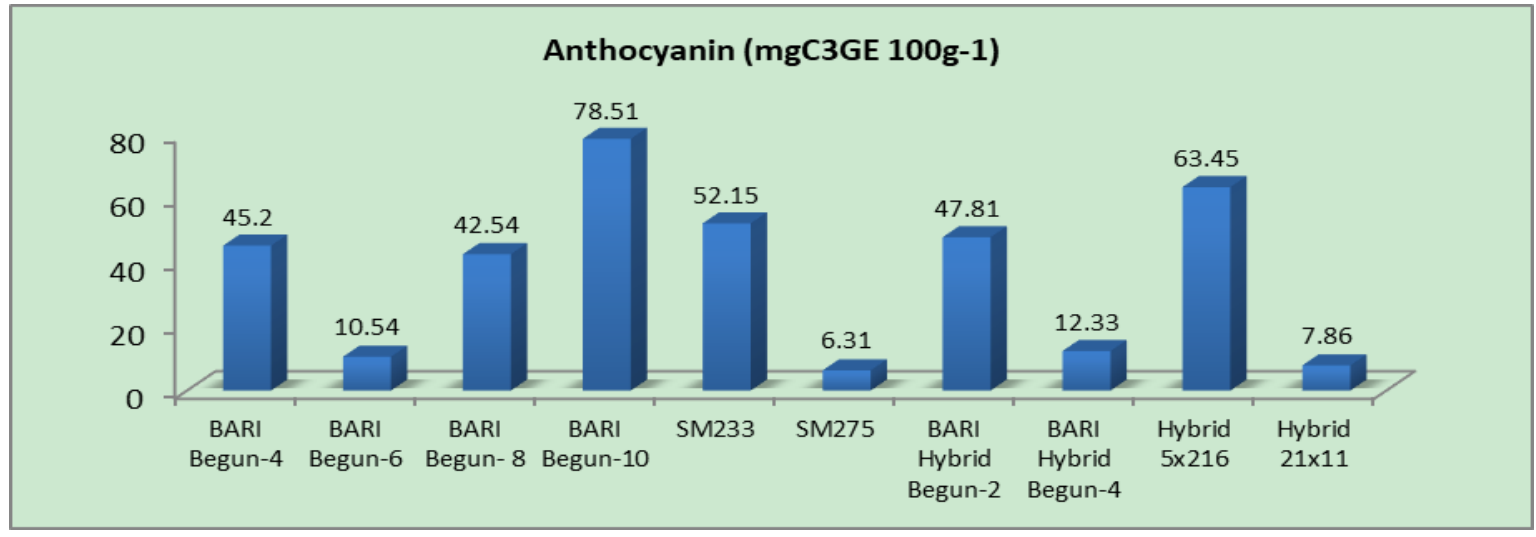

Figure 3. Anthocyanins amount $\left(\mathrm{mgC} 3 \mathrm{GE} 100 \mathrm{~g}^{-1}\right)$ of popular eggplant cultivars in Bangladesh 


\subsubsection{Mineral Content}

Mineral content values for the ten eggplant cultivars are shown in Table 3. Vegetables are characterized for the high content of mineral composition, especially in eggplant viz., $\mathrm{K}, \mathrm{Na}$, $\mathrm{Ca}, \mathrm{P}, \mathrm{Mg}, \mathrm{Fe}, \mathrm{Zn}, \mathrm{Mn}$ and $\mathrm{Cu}$. BARI Begun-6 had the highest values for $\mathrm{Ca}$, while BARI Begun-10 had the highest concentrations of P and Zn. BARI Hybrid Begun-4 reported the highest values for K, while the cultivar SM275 recorded the highest values for three minerals viz., Na, Mg and Mn and Hybrid 5x216 for Fe. The BARI Hybrid Begun-2 recorded the highest $\mathrm{Cu}$ content, but there were non-significant differences observed among the ten eggplant cultivars for $\mathrm{Cu}$ concentration. Na content varied largely in our study with a range from 4.06 to $8.51 \mathrm{mg} 100 \mathrm{~g}^{-1}$. It was similar to the findings of Nino-Medina et al. (2014),

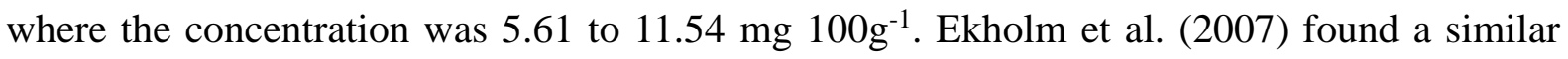
pattern and mineral content in eggplants cultivated in Finland, as compared to our work, where $\mathrm{K}$ displayed the highest concentration $\left(175 \mathrm{mg} 100 \mathrm{~g}^{-1}\right)$ and $\mathrm{Cu}$ displayed the lowest concentration (0.03 mg 100g-1). On the other hand, a study carried out in eggplants grown in Saudi Arabia by Mohamed et al. (2003) displayed different mineral concentrations (mg $100 \mathrm{~g}^{-1}$ ), reporting 274 for $\mathrm{Ca}, 222$ for $\mathrm{Na}$ and 212 for $\mathrm{K}$. Those values are higher than those recorded in our study.

Eggplants are a good source of biologically essential minerals like $\mathrm{K}, \mathrm{Ca}, \mathrm{Mg}, \mathrm{P}, \mathrm{Na}$ and $\mathrm{Fe}$. Their contents are similar to those found in tomatoes and higher than those reported in carrots, potatoes and onions, which are the most common vegetables consumed by the people.

Table 3. Minerals content of popular eggplant cultivars in Bangladesh (mg $100 \mathrm{~g}^{-1}$ fresh weight)

\begin{tabular}{l|c|c|c|c|c|c|c|c|c|c}
\hline Minerals & $\begin{array}{c}\text { BARI } \\
\text { Begun-4 }\end{array}$ & $\begin{array}{c}\text { BARI } \\
\text { Begun-6 }\end{array}$ & $\begin{array}{c}\text { BARI } \\
\text { Begun- } \\
8\end{array}$ & $\begin{array}{c}\text { BARI } \\
\text { Begun-10 }\end{array}$ & SM233 & SM275 & $\begin{array}{c}\text { BARI } \\
\text { Hybrid } \\
\text { Begun-2 }\end{array}$ & $\begin{array}{c}\text { BARI } \\
\text { Hybrid } \\
\text { Begun-4 }\end{array}$ & $\begin{array}{c}\text { Hybrid } \\
5 \times 216\end{array}$ & $\begin{array}{c}\text { Hybrid } \\
21 \times 11\end{array}$ \\
\hline $\mathrm{K}$ & 131.20 & 142.55 & 152.75 & 154.91 & 142.63 & 134.53 & 143.73 & 162.27 & 122.38 & 155.44 \\
$\mathrm{Na}$ & 4.14 & 4.79 & 6.54 & 7.23 & 7.32 & 8.51 & 4.89 & 5.32 & 4.90 & 4.06 \\
$\mathrm{Ca}$ & 30.27 & 48.33 & 31.78 & 33.93 & 45.93 & 33.94 & 35.74 & 30.28 & 47.59 & 26.62 \\
$\mathrm{P}$ & 14.45 & 20.67 & 21.09 & 23.45 & 18.26 & 19.37 & 21.94 & 15.91 & 18.46 & 20.62 \\
$\mathrm{Mg}$ & 19.30 & 18.21 & 15.42 & 21.40 & 20.69 & 24.80 & 17.67 & 21.40 & 21.61 & 19.30 \\
$\mathrm{Fe}$ & 1.44 & 1.35 & 1.50 & 1.86 & 1.60 & 1.17 & 1.40 & 1.65 & 5.00 & 0.91 \\
$\mathrm{Zn}$ & 0.22 & 0.45 & 0.56 & 0.57 & 0.36 & 0.42 & 0.47 & 0.49 & 0.36 & 0.52 \\
$\mathrm{Mn}$ & 0.37 & 0.36 & 0.40 & 0.25 & 0.33 & 0.41 & 0.30 & 0.29 & 0.26 & 0.32 \\
$\mathrm{Cu}$ & 0.15 & 0.14 & 0.12 & 0.14 & 0.14 & 0.13 & 0.16 & 0.14 & 0.10 & 0.14 \\
\hline
\end{tabular}

\section{Conclusion}

The ten eggplant cultivars were evaluated in two ways viz., morphological characteristics and nutritional composition. In both studies the four OP cultivars viz., BARI Begun-6, BARI 
Begun-8, BARI Begun-10, SM275 and one hybrid viz., Hybrid 21x11 performed well with better horticultural characteristics along with significant concentrations of some human promoting health components, such as crude fibre and biologically essential minerals like $\mathrm{K}$, $\mathrm{Ca}, \mathrm{Mg}, \mathrm{P}, \mathrm{Na}$ and $\mathrm{Fe}$. They also provide important amounts of antioxidants like ascorbic acid and anthocyanin. These cultivars can therefore be cultivated and consumed for better human health.

\section{References}

Abdel-Aal, E. S., \& Hucl, P. (1999). A rapid method for quantifying total anthocyanins in blue aleurone and purple pericarp wheats. Cereal Chem., 76(3), 350-354. https://doi.org/10.1094/CCHEM.1999.76.3.350

Anonymous. (1995). Agro-climatatrological data. Agromet Division, Bangladesh Meteorological Department, Joydebpur, Gazipur. pp. 35-65.

AOAC. (1998). Official Methods of Analysis. Association of Official Analytical Chemist. Maryland, AOAC International.

Caguiat, X. G. I., \& Hautea, D. M. (2014). Genetic diversity analysis of eggplant (Solanum melongena L.) and related wild species in the Philippines using morphological and SSR markers, Sabrao J Breed Genet., 46(2), 183-201.

Cao, G., Sofic, E., \& Prior, R. L. (1996). Antioxidant capacity of tea and common vegetables. J Agr Food Chem., 44, 3426-3431. https://doi.org/10.1021/jf9602535

Doner, L. W., \& Hicks, K. B. (1981). High-performance liquid chromatographic separation of ascorbic acid, erythorbic acid, dehydroascorbic acid, dehydroerythorbic acid and $\begin{array}{llll}\text { diketogluconic acid. Anal } & \text { 225-230. }\end{array}$ https://doi.org/10.1016/0003-2697(81)90550-9

Durust, N., Sumengen, D., \& Durust, Y. (1997). Ascorbic acid and element contents of foods of Trabzon (Turkey). Journal of Agricultural and Food Chemistry, 45, 2085-2087. https://doi.org/10.1021/jf9606159

Ekholm, P., Reinivuo, H., Mattila, P., Pakkala, H., Koponen, J., Happonen, A., ... Ovaskainen, M. L. (2007). Changes in the mineral and trace element contents of cereals, fruits and vegetables in Finland. $J$ Food Compos Anal., 20(6), 487-495. https://doi.org/10.1016/j.jfca.2007.02.007

Esteban, R. M., Molla, E. M., Robredo, F. J., \& Lopez-Andreu, F. J. (1992). Changes in the chemical composition of eggplant fruits during development and ripening. J. Agr. Food Chem., 40(6), 998-1000. https://doi.org/10.1021/jf00018a017

Flick, G. J., Burrnette, F. S., Aung, L. H., Ory, R. L., \& St Angelo, A. J. (1978). Chemical composition and biochemical properties of mirlitons (Sechium edule) and purple, green and white eggplants (Solanum melongena). J. Agr. Food Chem., 26(5), 1000-1005. https://doi.org/10.1021/jf60219a045 
Hanson, P. M., Yang, R. Y., Tsou, S. C., Ledesma, D., Engle, L., \& Lee, T. C. (2006). Diversity in eggplant (Solanum melongena) for superoxide scavenging activity, total phenolics and ascorbic acid. J. Food Compos Anal., 19(6-7), 594-600. https://doi.org/10.1016/j.jfca.2006.03.001

Kantharajah, A. S., \& Golegaonkar, P. G. (2004). Somatic embryogenesis in eggplant. Sci Hortic-Amsterdam, 99(2),107-117. https://doi.org/10.1016/S0304-4238(03)00090-6

Kashyap, V., Kumar, S. V., Collonnier, C., Fusari, F., Haicour, R., Rotino, G. L., Sihachakr, D., \& Rajam, M. V. (2003). Biotechnology of eggplant. Sci Hortic-Amsterdam, 97(1), 1-25. https://doi.org/10.1016/S0304-4238(02)00140-1

Koponen, J. M., Happonen, A. M., Mattila, P. H., \& Torronen, R. (2007). Contents of anthocyanins and ellagitannins in selected foods consumed in Finland. J. Agr. Food Chem., 55(4), 1612-1619. https://doi.org/10.1021/jf062897a

Korkmaz, A. I., Akgul, H., Sevindik, M., \& Selamoglu, Z. (2018). Study on determination of bioactive potentials of certain lichens. Acta Alimentaria, 47(1), 80-87. https://doi.org/10.1556/066.2018.47.1.10

Kumari, A., Chawla, N., \& Dhatt, A. S. (2018). Genotypic Differences for Anthocyanins in Different parts of Eggplant (Solanum melongena L.). Int. J. Adv. Res. Biol. Sci., 5(1), 12-18. https://doi.org/10.22192/ijarbs.2018.05.01.003

Lo Scalzo, R., Fibiani, M., Mennella, G., Rotino, G. L., Dal Sasso, M., Culici, M., Spallino, A., \& Braga, P. C. (2010). Thermal treatment of eggplant (Solanum melongena L.) increases the antioxidant content and the inhibitory effect on human neutrophil burst. J. Agr. Food Chem. 58(6), 3371-3379. https://doi.org/10.1021/jf903881s

Manach, C., Scalbert, A., Morand, C., Remesy, C., \& Jimenez, L. (2004). Polyphenols: food sources and bioavailability. Am. J. Clin. Nutr., 79(5), 727-747. https://doi.org/10.1093/ajcn/79.5.727

Maroto, J. V. (2002). Horticultura Herbacea Especial. 5th Ed. Ediciones Mundi-Prensa. Mexico. pp. 481-495.

Matsuzoe, N., Yamaguchi, M., Kawanobu, S., Watanabe, Y., Higashi, H., \& Sakata, Y. (1999). Effect of dark treatment of the eggplant on fruit skin colour and its anthocyanin component. $J$. Jpn. Soc. Hortic. Sci., 68(1), 138-145. https://doi.org/10.2503/jjshs.68.138

Mohamed, A. E., Rashed, M. N., \& Mofty, A. (2003). Assessment of essential and toxic elements in some kinds of vegetables. Ecotox Environ Safe, 55(3), 251-60. https://doi.org/10.1016/S0147-6513(03)00026-5

Munoz de Chavez, M., Chavez, A., Roldan, J., Ledesma, J., Mendoza, E., \& Perez-Gil, F. (1996). Tablets of nutritional value of foods: of greater consumption in Mexico / Tablets of nutritional value of foods: of greater consumption in Mexico / List of nutritive value of foods: the biggest consumption in Mexico. México, DF; Editorial Pax México. P.330. 
Nino-Medina, G., D. Muy-Rangel, A. Gardea-Bejar, G. Gonzalez-Aguilar, B. Heredia, M. Baez-Sanudo, J. Siller-Cepeda, \& R. Velez De La Rocha. (2014). Nutritional and Nutraceutical Components of Commercial Eggplant Types Grown in Sinaloa, Mexico. Not. Bot. Horti. Agrobo., 42(2), 538-544. https://doi.org/10.15835/nbha4229573

Ozgur, M. U., \& Sungur, S. (1995). Third order derivative spectrophotometric determination of ascorbic acid in fruits and vegetables. Talanta, 42(11), 1631-1640. https://doi.org/10.1016/0039-9140(95)01622-8

Papanga, G., Miller, N., \& Rice-Evans, C. A. (1999). The polyphenolic content of fruit and vegetables and their antioxidant activities. What does a serving constitute? Free Radical Res., 30(2), 153-162. https://doi.org/10.1080/10715769900300161

Prohens, J., Rodriguez-Burruezo, A., Raigon, M. D., \& Nuez, F. (2007). Total phenolic concentration and browning susceptibility in a collection of different varietal types and hybrids of eggplant:implications for breeding for higher nutritional quality and reduced browning. J. Am. Soc. Hortic. Sci., 132(5), 638-646. https://doi.org/10.21273/JASHS.132.5.638

Raigon, M. D., Prohens, J., Munoz-Falcon, J. E., \& Nuez, F. (2008). Comparison of eggplant landraces and commercial varieties for fruit content of phenolics, minerals, dry matter and protein. J. Food Compos. Anal. 21(5), 370-376. https://doi.org/10.1016/j.jfca.2008.03.006

Sadilova, E., Stintzing, F. C., \& Carle, R. (2006). Anthocyanins, colour and antioxidant properties of eggplant (Solanum melongena L.) and violet pepper (Capsicum annuum L.) peel extracts. Z Naturforsch C 61(7-8), 527-535. https://doi.org/10.1515/znc-2006-7-810

Sanchez-Castillo, C. P., Englyst, H. N., Hudson, G. J., Lara, J. J., Solano, M. L., Munguia J. L., \& James, W. P. (1999). The non-starch polysaccharide content of Mexican foods. J. Food Compos. Anal., 12(4), 293-314. https://doi.org/10.1006/jfca.1999.0831

Scalbert, A., \& Williamson, G. (2000). Dietary intake and bioavailability of polyphenols. $J$. Nutr. 130(8), 2073S-2085S. https://doi.org/10.1093/jn/130.8.2073S

Sevindik, M, Akgul, H., Pehlivan, M., \& Selamoglu, Z. (2017). Determination of therapeutic potential of Mentha longifolia ssp. longifolia. Fresen Environ. Bull., 26(7), 4757-4763.

Sevindik, M. (2019). The novel biological tests on various extracts of Cerioporus varius. Fresenius Environ. Bulletin, 28(5), 3713-3717.

Sevindik, M., Rasul, A., Hussain, G., Anwar, H., Zahoor, M. K., Sarfraz, I., ... Selamoglu Z. (2018). Determination of anti-oxidative, anti-microbial activity and heavy metal contents of Leucoagaricus leucothites. Pak. J. Pharma. Sc., 31 (5 (Supplementary)), 2163-2168.

Sihachkr, D., Chaput, M. H., Serraf, I., Ducreux, G. (1993). Regeneration of plants from protoplasts of eggplant (Solanum melongena L.). In: Bajaj, Y.P.S. (Ed.), Biotechnology in Agriculture and Forestry, Plant Protoplasts and Genetic Engineering. Springer, Berlin, pp. 108-122. https://doi.org/10.1007/978-3-642-78037-0_9 


\section{Macrothink}

United States Department of Agriculture (USDA) (2014). USDA National Nutrient Database for Standard Reference. http://www.nal.usda.gov/fnic/foodcomp/search.

Vavilov, N. (1928). Proc. Fifth International Congress of Genetics. New York, pp. 342- 369.

Young M. (1999). How much vitamin C do you need? J Am Med Assoc., 281(15). 1460. https://doi.org/10.1001/jama.281.15.1460

\section{Copyright Disclaimer}

Copyright for this article is retained by the author(s), with first publication rights granted to the journal.

This is an open-access article distributed under the terms and conditions of the Creative Commons Attribution license (http://creativecommons.org/licenses/by/4.0/). 